\title{
Centrally Delivered BACE1 Inhibitor Activates Microglia, and Reverses Amyloid Pathology and Cognitive Deficit in Aged Tg2576 Mice
}

\author{
Deepak R. Thakker, ${ }^{1 *}$ Sethu Sankaranarayanan, ${ }^{3 *}$ ๑Marcy R. Weatherspoon, ${ }^{2}{ }^{\oplus}$ Jonathan Harrison, ${ }^{1}$ \\ Maria Pierdomenico, ${ }^{3}$ Jennifer M. Heisel, ${ }^{1}$ Lorin A. Thompson, ${ }^{4}$ Roy Haskell,,${ }^{5}$ OJames E. Grace, ${ }^{6}$ Sarah J. Taylor, ${ }^{6}$ \\ Charles F. Albright, ${ }^{3}$ and ${ }^{\circ}$ Lisa L. Shafer ${ }^{1}$ \\ ${ }^{1}$ Neuromodulation Global Research, Technology \& Development, ${ }^{2}$ Strategy \& Scientific Operations, Medtronic, Minneapolis, Minnesota 55432-5604, and \\ ${ }^{3}$ Neuroscience, ${ }^{4}$ Chemistry, ${ }^{5}$ Pharmaceutics, and ${ }^{6}$ Metabolism \& Pharmacokinetics, Bristol-Myers Squibb, Wallingford, Connecticut 06492
}

Multiple small-molecule inhibitors of the $\beta$-secretase enzyme (BACE1) are under preclinical or clinical investigation for Alzheimer's disease (AD). Prior work has illustrated robust lowering of central amyloid $\beta(\mathrm{A} \beta)$ after acute administration of BACE1 inhibitors. However, very few studies have assessed the overall impact of chronically administered BACE1 inhibitors on brain amyloid burden, neuropathology, and behavioral function in aged preclinical models. We investigated the effects of a potent nonbrain-penetrant BACE1 inhibitor, delivered directly to the brain using intracerebroventricular infusion in an aged transgenic mouse model. Intracerebroventricular infusion of the BACE1 inhibitor (0.3-23.5 $\mu \mathrm{g} / \mathrm{d}$ ) for 8 weeks, initiated in 17-month-old Tg2576 mice, produced dose-dependent increases in brain inhibitor concentrations $(0.2-13 \mu \mathrm{M})$. BACE1 inhibition significantly reversed the behavioral deficit in contextual fear conditioning, and reduced brain $\mathrm{A} \beta$ levels, plaque burden, and associated pathology (e.g., dystrophic neurites), with maximal effects attained with $\sim 1 \mu \mathrm{g} / \mathrm{d}$ dose. Strikingly, the BACE1 inhibitor also reversed amyloid pathology below baseline levels (amyloid burden at the start of treatment), without adversely affecting cerebral amyloid angiopathy, microhemorrhages, myelination, or neuromuscular function. Inhibitor-mediated decline in brain amyloid pathology was associated with an increase in microglial ramification. This is the first demonstration of chronically administered BACE1 inhibitor to activate microglia, reverse brain amyloid pathology, and elicit functional improvement in an aged transgenic mouse model. Thus, engagement of novel glial-mediated clearance mechanisms may drive diseasemodifying therapeutic benefit with BACE1 inhibition in AD.

\section{Introduction}

Alzheimer's disease $(\mathrm{AD})$ is a progressive neurodegenerative disorder characterized by a decline in cognitive and memory functions and by an aberrant accumulation of brain amyloid plaques derived from amyloid $\beta(\mathrm{A} \beta)$ peptides. Consistent with the hypothesis that accumulation of $A \beta$ contributes to disease pathogenesis, $A \beta$-lowering agents and antibodies have presented promising therapeutic avenues for AD. Several late-stage trials with anti-A $\beta$ antibodies and $\gamma$-secretase inhibitors recently failed

\footnotetext{
Received June 3, 2014; revised Feb. 13, 2015; accepted March 23, 2015.

Author contributions: D.R.T., S.S., C.F.A., and L.L.S. designed research; D.R.T., S.S., M.R.W., J.H., M.P., J.M.H., J.E.G., and S.J.T. performed research; S.S., L.A.T., and R.H. contributed unpublished reagents/analytic tools; D.R.T., S.S., M.R.W., J.H., M.P., J.M.H., J.E.G., and S.J.T. analyzed data; D.R.T., S.S., C.F.A., and L.L.S. wrote the paper.

This work was supported by Medtronic and Bristol-Myers Squibb. We sincerely acknowledge the meticulous data analyses support from Bradley Nix.

All authors were, at the time of the work, employees of Medtronic or Bristol-Myers Squibb as indicated.

*D.R.T. and S.S. contributed equally to this work.

M.R. Weatherspoon's present address: Cardiovascular Systems, Minneapolis, MN.

J. Harrison's present address: University of Utah School of Medicine, Salt Lake City, UT.

J.M. Heisel's present address: St. Jude Medical, Minneapolis, MN.

L.L. Shafer's present address: Upsher-Smith Laboratories, Minneapolis, MN

Correspondence should be addressed to Lisa L. Shafer, 6701 Evenstad Drive, Maple Grove, MN 55369-6026.

E-mail: lisa.shafer@upsher-smith.com.

DOI:10.1523/JNEUROSCI.2262-14.2015

Copyright $\odot 2015$ the authors $\quad 0270-6474 / 15 / 356931-06 \$ 15.00 / 0$
}

to meet primary clinical endpoints due to lack of target engagement and/or side effects that prevented testing of therapeutically relevant doses (Aisen et al., 2013; Toyn and Ahlijanian, 2014). However, inhibitors of the $\beta$-secretase (BACE1) enzyme have shown robust lowering of CSF A $\beta$ levels in young healthy subjects, and are in late-stage clinical trials for $\mathrm{AD}$ (Yan and Vassar, 2014), raising interest in elucidating underlying mechanisms of BACE1 inhibition in aging models.

BACE1 is a promising drug target, since mutations of the amyloid precursor protein (APP) that increase its cleavage by $\mathrm{BACE} 1$ increase the risk for $\mathrm{AD}$, while others that inhibit cleavage by BACE1 significantly reduce the risk for $\mathrm{AD}$ and age-related cognitive decline (Vassar et al., 2009; Jonsson et al., 2012). BACE1 knock-outs rescue amyloid pathology and behavioral deficits in mutant APP-overexpressing mice (for review, see Vassar et al., 2009). Whereas altered processing of neuregulin and myelination are evident in young mice lacking BACE1 (Hu et al., 2006; Willem et al., 2006), they appear to be unaltered in adult BACE1 knockout mice or with subchronic BACE1 inhibition in APPoverexpressing mice (Sankaranarayanan et al., 2008). BACE1 inhibitors can reduce brain $A \beta$ levels, prevent amyloid pathology, or improve behavioral function when tested in young animals before development of extensive pathology (for review, see 
A$$
\text { A }
$$

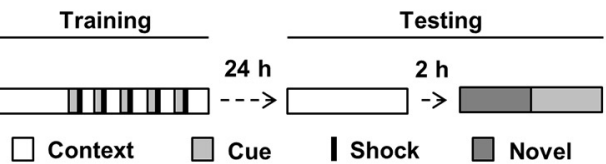

B

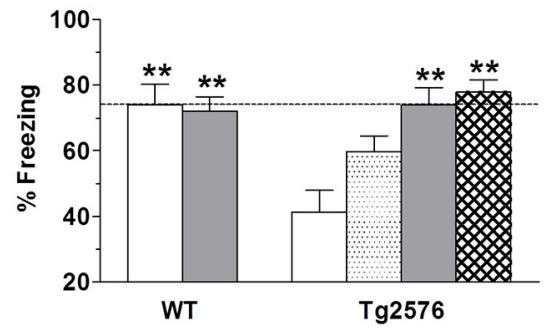

8898 Baseline (harvest at $17.2 \mathrm{mo}$ )

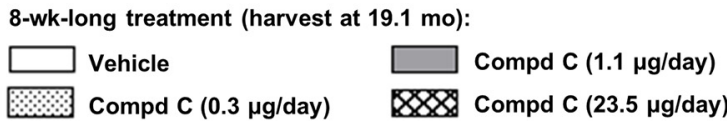

C
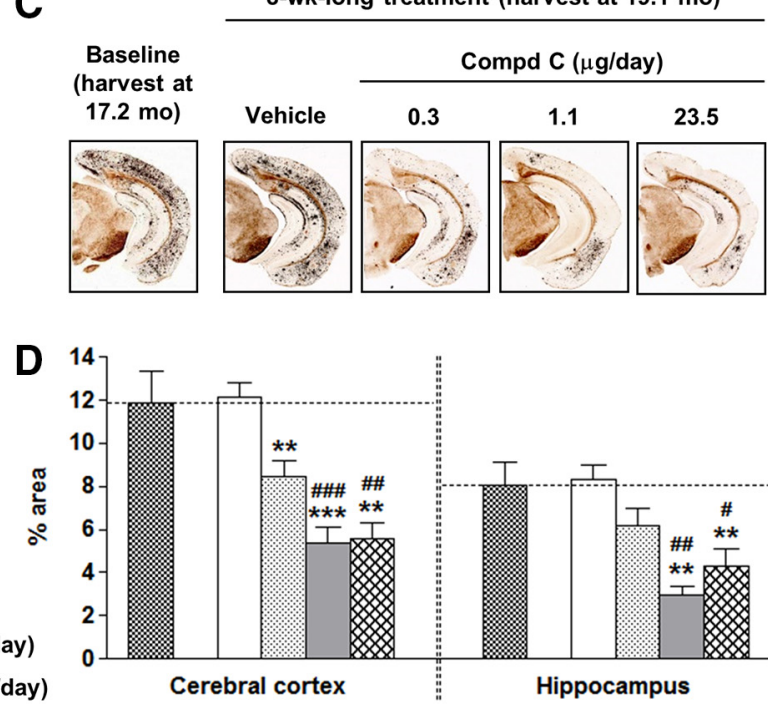

Figure 1. Chronic intracerebroventricular infusion with BACE1 inhibitor, compound C, rescued behavioral deficit and reversed amyloid burden in aged Tg2576 mice. $\boldsymbol{A}$, Fear-conditioning paradigm: mice were trained on day 1 in a specific context with a series of conditioning stimuli (tone cue followed by mild foot-shock). On day 2 , freezing was evaluated in the same context (contextual fear memory), novel context (baseline), or cue alone (cued fear memory). B, Vehicle-treated Tg2576 mice show a deficit in contextual memory, compared with WT mice. A dosedependent improvement in contextual fear memory was evident with intracerebroventricularly infused compound C. C, Low-magnification ( $\times 4)$ images illustrate amyloid plaques stained with Campbell-Switzer stain in cortex and hippocampus of $\operatorname{Tg} 2576$ mice at baseline and 8 weeks after intracerebroventricular infusion with vehicle or compound $C$. $D$, Percentage area occupied by amyloid plaques in vehicle-treated and compound C-treated mice. Significance versus vehicle-treated mice $\left({ }^{* *} p<0.01,{ }^{* * *} p<0.001\right)$ and versus baseline $\left.{ }^{\#} p<0.05,{ }^{\# \#} p<0.01,{ }^{\# \# \#} p<0.001\right)$.

Table 1. Chronic intracerebroventricular infusion with compound C does not alter CAA, microhemorrhages, integrity of myelin, or neuromuscular function in aged Tg2576 mice $^{a}$

\begin{tabular}{|c|c|c|c|c|c|c|c|c|}
\hline \multirow[b]{2}{*}{ Treatment } & \multirow[b]{2}{*}{ Daily dose ( $\mu \mathrm{g} / \mathrm{d})$} & \multirow[b]{2}{*}{ CAA (\% area) } & \multicolumn{2}{|c|}{ Microhemorrhages } & \multirow[b]{2}{*}{ Grip strength (g) } & \multicolumn{3}{|l|}{ Myelin integrity } \\
\hline & & & Frequency & Severity & & Corpus callosum $\left(\mathrm{mm}^{3}\right)$ & Striatum (\% area) & Sciatic nerve (g-ratio) \\
\hline \multirow[t]{3}{*}{ Compound C } & 0.3 & $0.75 \pm 0.09$ & $3.4 \pm 0.5$ & $1.2 \pm 0.1$ & $205.1 \pm 8.6$ & $0.35 \pm 0.01$ & $25.9 \pm 2.5$ & $0.61 \pm 0.01$ \\
\hline & 1.1 & $0.67 \pm 0.08$ & $3.5 \pm 0.7$ & $1.2 \pm 0.1$ & $200.5 \pm 8.1$ & $0.38 \pm 0.01$ & $23.4 \pm 1.7$ & $0.59 \pm 0.01$ \\
\hline & 23.5 & $0.89 \pm 0.17$ & $4.1 \pm 0.5$ & $1.5 \pm 0.2$ & $221.5 \pm 10.1$ & $0.40 \pm 0.02$ & $26.6 \pm 4.0$ & $0.59 \pm 0.01$ \\
\hline Vehicle & - & $0.83 \pm 0.11$ & $3.9 \pm 0.4$ & $1.2 \pm 0.1$ & $213.4 \pm 6.6$ & $0.38 \pm 0.01$ & $20.4 \pm 1.0$ & $0.59 \pm 0.01$ \\
\hline
\end{tabular}

${ }^{a}$ Quantitation of CAA in leptomeninges and vasculature within brain cortices and hippocampi. Frequency of cerebral microhemorrhages analyzed by counting the number of perivascular hemosiderin-positive cell clusters per section (average of $18-20$ sections per brain). Microhemorrhage severity estimated by assigning a grade of $1-4$ for clusters of 1-4,5-10,11-20, or $>20$ hemosiderin-positive cells, respectively. Grip-strength recordings taken for all limbs and averaged over five trials per mouse. Myelin integrity measured using $g$-ratios, Caveliari's volumetric method, and percentage area occupied by myelin-positive signal, for peripheral (sciatic nerves), and central (corpus callosum, striatum) nerve fibers.

Ghosh et al., 2012). However, studies assessing prolonged exposures in aged preclinical models are necessary to predict treatment effects in clinical AD.

We sought to determine whether chronic exposure to a potent BACE1 inhibitor could affect brain amyloid pathology and behavioral deficit in aged Tg2576 mice, which have significant pathology before onset of treatment. Our data provide the first evidence for behavioral improvement, reduction in amyloid pathology below pretreatment levels, and engagement of microglia as a potential underlying mechanism following BACE1 inhibition in an aged APP transgenic mouse model. These findings offer novel insights supporting BACE1 inhibition as a viable therapeutic with potential for disease-modifying effects in AD.

\section{Materials and Methods}

Mice and experimental design. The Animal Care and Use Committee at Medtronic's Physiological Research Laboratory, accredited by the Association for Assessment and Accreditation of Laboratory Animal Care, approved all procedures. Male Tg2576, overexpressing $\mathrm{APP}_{\mathrm{SWE}}$, the Swedish $\beta$-site mutant form of APP, and corresponding wild-type (WT) mice (B6/SJL background; Taconic), aged 16.5-17.7 months, were uniformly distributed across treatment groups to implant osmotic minipumps (Alzet model 2006; Durect) for subcutaneous or intracerebroventricular infusion of the BACE1 inhibitor (compound C; in vitro $\mathrm{IC}_{50}, 2-8 \mathrm{~nm}$; Meredith et al., 2008).
Tg2576 mice received intracerebroventricular infusions of compound $(0.3 \mu \mathrm{g} / \mathrm{d}, n=12 ; 1.1 \mu \mathrm{g} / \mathrm{d}, n=13 ; 23.5 \mu \mathrm{g} / \mathrm{d}, n=12)$ or vehicle alone $(n=14)$. As previously described for intracerebroventricular infusion (Thakker et al., 2009), osmotic minipumps were connected via catheters to brain-infusion cannulae and placed subcutaneously, before stereotaxically implanting the cannulae on the skull. PBS, $\mathrm{pH} 7.2$, provided the vehicle for 0.3 and $1.1 \mu \mathrm{g} / \mathrm{d}$ doses, while the $23.5 \mu \mathrm{g} / \mathrm{d}$ dose was formulated in 1:1 PEG300/DMSO solution due to limited solubility. The two intracerebroventricular vehicle groups revealed no significant differences for any study outcome, and were combined into a single vehicle group. Other transgenic mice received subcutaneous infusions of compound C $(1.1 \mu \mathrm{g} / \mathrm{d}, n=9)$ or PBS vehicle $(n=10)$. WT mice provided phenotype controls (intracerebroventricular vehicle, $n=10$; intracerebroventricular compound C, $1.1 \mu \mathrm{g} / \mathrm{d}, n=10$; subcutaneous vehicle, $n=$ 10 ; subcutaneous compound $\mathrm{C}, 1.1 \mu \mathrm{g} / \mathrm{d}, n=10)$. Infusion of test articles, with endotoxin levels $<0.03$ endotoxin units $/ \mathrm{ml}$, was performed for 8 weeks, starting at age $\sim 17.2$ months and terminating at $\sim 19.1$ months.

At termination, CSF samples were withdrawn, and mice transcardially perfused with ice-cold saline to harvest tissue. Ipsilateral and contralateral brain hemispheres, relative to the infused right lateral ventricle, were randomly assigned for biochemical and histological analyses. Similar to prior work with larger molecules (Thakker et al., 2009), data from both pilot and present studies revealed no significant differences between the two brain hemispheres for any outcomes.

Behavioral assessment. A week before termination, mice were tested for contextual and cued memory, as illustrated in Figure $1 A$ and previously 
Vehicle

Compd C (0.3 $\mu \mathrm{g} / \mathrm{day})$

\section{Compd C (1.1 $\mu \mathrm{g} / \mathrm{day})$ Compd C (23.5 $\mu \mathrm{g} /$ day $)$}
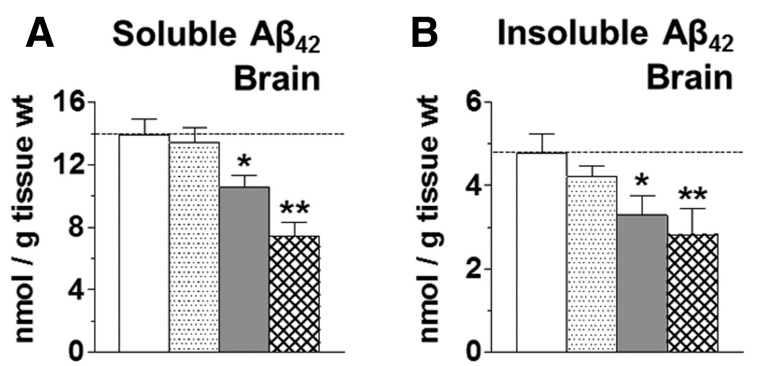

C

$\operatorname{CSF~A\beta _{42}}$
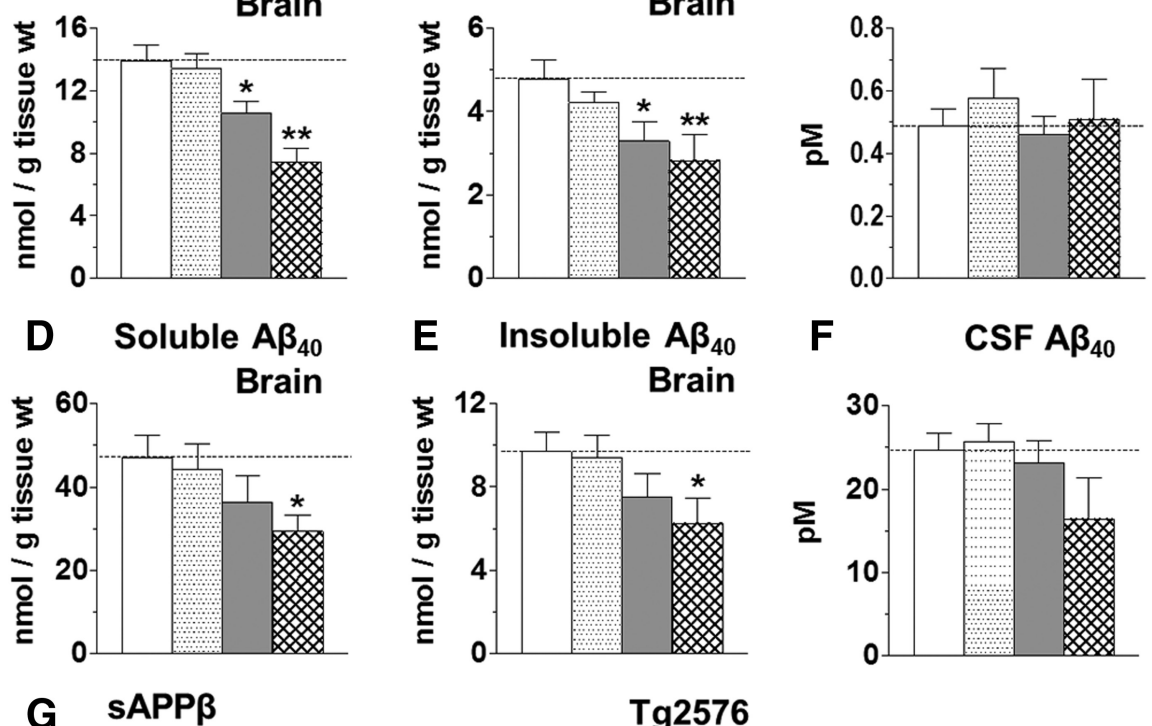

F

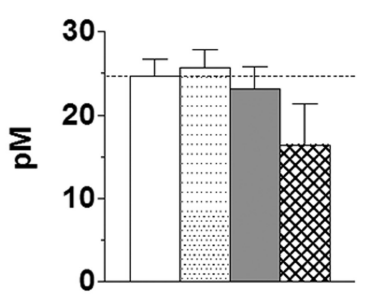

Tg2576

Brain extractions and A $\beta$ ELISA. Brain samples were extracted using $0.2 \%$ diethylamine for soluble $\mathrm{A} \beta$ (Sankaranarayanan et al., 2008), followed by $70 \%$ formic acid for insoluble $\mathrm{A} \beta$ as previously described (Kawarabayashi et al., 2001). We used previously published methods to measure brain compound levels (Meredith et al., 2008), and sandwich ELISAs to measure brain and CSF A $\beta$ levels (Easton et al., 2013).

Statistical analyses. All analyses were performed blind to treatment. An average score was used when two individuals scored the outcomes; the interscorer reliability ranged from 0.955 to $0.989(p<0.0001)$. Data are expressed as mean \pm SEM. Statistical analyses used GraphPad Prism 4.0 (GraphPad) to perform one-way ANOVA followed by Tukey's post hoc test for all analyses, except microhemorrhage severity, which was analyzed using Kruskal-Wallis followed by Dunn's multiple-comparison test. Differences were considered significant at $p<$ 0.05 .

\section{Results}

Dose-dependent increases in compound levels within the brain parenchyma were observed in $\sim 19.1$-month-old Tg2576 mice following intracerebroventricular infusion of the BACE1 inhibitor (compound C) over 8 weeks: $0.25 \pm 0.06$, $0.71 \pm 0.26$, and $13.21 \pm 5.15 \mu \mathrm{M}$, for infusions maintained at $0.3,1.1$, and 23.5 $\mu \mathrm{g} / \mathrm{d}$, respectively. In contrast, brain exposures were negligible in the subcutaneous infusion group: $0.01 \pm 0.01 \mu \mathrm{M}$ with $1.1 \mu \mathrm{g} / \mathrm{d}$ infusion. Robust brain compound exposures with intracerebroventricular delivery allowed testing hypotheses on multiple functional, biochemical, and pathological endpoints following chronic BACE1 inhibition.

Aged Tg2576 mice exhibit substantial deficit in contextual fear conditioning compared with WT littermates (Jacobsen et al., 2006). Compound C elicited a sig-

described (Thakker et al., 2009). Locomotor activity was assessed in a cubical arena $\left(40 \mathrm{~cm}^{3}\right)$ for $\leq 1 \mathrm{~h}$ using the Limelight video tracking system (Coulbourn Instruments). Grip strength for all limbs was measured using the grip strength meter (Columbus Instruments).

Histology. Brain hemispheres were fixed in paraformaldehyde ( $4 \%$ in saline) and, using MultiBrain Technology (NeuroScience Associates), coronally sectioned at $35 \mu \mathrm{m}$. For each stain, we used a series of $18-20$ sections, equally spaced at $350 \mu \mathrm{m}$ intervals, across the entire cerebrum. Accordingly, analyses involved an average from multiple observations per hemisphere per animal, as follows: cortex (18-20), hippocampus (7-9), striatum (9-11), corpus callosum (14). We quantified parenchymal amyloid plaques, dense-core plaques, cerebral amyloid angiopathy (CAA), cerebral microhemorrhages, dystrophic neurites, and activated microglia, using protocols described previously (Thakker et al., 2009). We evaluated brain sAPP $\beta$ (secreted form of $\beta$-APP) using an antibody specific to the neoepitope ISEVNL of sAPP $\beta$ derived from BACE1 cleavage of $\mathrm{APP}_{\mathrm{SWE}}$ (1:1500, clone 6A1, IBL International; Fukumoto et al., 2010). Sciatic nerves were individually embedded in blocks of glycol methacrylate, coronally sectioned at $2 \mu \mathrm{m}$, and visualized with modified Lee's stain. $G$-ratios were quantified as a ratio of inner circumference of the axon (without myelin) over the outer circumference of the nerve fiber (including myelin), for $\geq 32$ axons from four nerve segments collected per animal (Midwest ToxPath Sciences). nificant dose-dependent reversal of this deficit, with complete reversal noted at $1.1 \mu \mathrm{g} / \mathrm{d}$ infused intracerebroventricularly (Fig. $1 B)$. In contrast, the same dose failed to alter behavioral responses after subcutaneous infusion in transgenic mice $(p=0.8)$, or with either intracerebroventricular (Fig. $1 B$ ) or subcutaneous delivery in WT mice $(p=0.5)$. The effects of intracerebroventricularly infused compound $\mathrm{C}$ were specific to contextual memory deficits, with cued-conditioning behavior $(p=0.3)$ and general locomotion $(p=0.5)$ being unchanged. Vehicle-infused transgenics exhibited hyperlocomotion $(p<0.01)$, but no changes in cued fear conditioning relative to vehicle-infused WTs ( $p=0.67)$. The brain compound $\mathrm{C} \mathrm{EC}_{50}$ for rescue of contextual fear memory was $\sim 0.25 \pm 0.06 \mu \mathrm{M}$. These results demonstrate that chronic BACE1 inhibition can reverse behavioral deficits in aged Tg2576 mice.

Using histology and biochemical endpoints, we evaluated the impact of chronic BACE1 inhibition on amyloid burden. Tg2576 mice show robust levels of amyloid burden at $\geq 16$ months of age (Kawarabayashi et al., 2001). Consistent with this finding, we observed extensive plaque burden in the cortex and hippocam- 
pus of our cohort at baseline (age, $\sim 17.2$ months), with insignificant increases in the plaque burden in vehicle-treated mice at end of study (age, $\sim 19.1$ months; Fig. $1 C, D)$. Whereas subcutaneous infusion of compound $\mathrm{C}$ failed to alter cortical $(p=0.9)$ or hippocampal $(p=0.8)$ plaque load, intracerebroventricular infusion produced a dose-dependent reduction of plaques in both brain regions (Fig. $1 C, D)$, with maximal effects obtained with the $1.1 \mu \mathrm{g} / \mathrm{d}$ dose. In particular, intracerebroventricular doses of 1.1 and $23.5 \mu \mathrm{g} / \mathrm{d}$ significantly reduced the plaque burden by $>45 \%$, compared with not only vehicle-treated animals but also baseline animals (Fig. 1D). Similarly, dense-core plaques decreased by $\leq 52 \%$ in mice treated with intracerebroventricular BACE1 inhibitor, relative to the plaques present in vehicle-treated $(p<0.01)$ or baseline $(p<0.05)$ animals (data not shown). Subcutaneously delivered inhibitor had no effects $(p=0.9)$. CAA or microhemorrhages were unaltered with intracerebroventricular (Table 1) or subcutaneous infusions $(p=0.9$, CAA; $p=0.6$, microhemorrhages).

In agreement with its effects on amyloid plaques, intracerebroventricularly delivered compound $\mathrm{C}$ significantly decreased both soluble and insoluble A $\beta 42$ levels in the brain by $\leq 47$ and $\leq 41 \%$, respectively (Fig. $2 A, B$ ). A trend for reduction in soluble and insoluble $A \beta 40$ in the brain was also evident with a significant decline $(\sim 35 \%)$ in the $23.5 \mu \mathrm{g} / \mathrm{d}$ dose (Fig. $2 D, E$ ). Unlike brain $\mathrm{A} \beta$, CSF $\mathrm{A} \beta 40$ or $\mathrm{A} \beta 42$ remained unchanged with treatment (Fig. 2C,F). Subcutaneously delivered compound had no significant impact on biochemical outcomes $(p=0.8$, soluble $\mathrm{A} \beta 42 ; p=0.9$, insoluble $\mathrm{A} \beta 42 ; p=$ 0.1, CSF $\mathrm{A} \beta 42 ; p=0.7$, soluble $\mathrm{A} \beta 40 ; p=$ 0.9 , insoluble $A \beta 40 ; p=0.2$, CSF $A \beta 40$ ). Consistent with the ring-like staining of BACE1 observed around clear cores of unstained amyloid plaques in aged Tg2576 mice (Zhao et al., 2007), we noted

a robust ring-like sAPP $\beta$ immunostaining in Tg2576, but not in WT, mice (Fig. 2G). Brain sAPP $\beta$ immunostaining was reduced in mice infused with compound $\mathrm{C}$ (Fig. $2 G$ ), providing direct evidence for BACE1 inhibition in aged Tg2576 mice.

Dystrophic neurites were visualized, using the deOlmos silver stain, as black rings of swollen distorted axons or dendrites surrounding dense-core amyloid plaques (Fig. $3 A$ ). A significant decline in dystrophic neurites was evident with $\sim 53 \%$ reduction with the $1.1 \mu \mathrm{g} / \mathrm{d}$ dose of the intracerebroventricularly infused compound (Fig. 3B). Subcutaneously infused compound did not elicit any effects $(p=0.9)$. GFAP-positive astrocytotic clusters also showed a dose-dependent reduction by $\leq 49 \%$ upon chronic intracerebroventricular, but not subcutaneous ( $p=0.6)$, infusion of the BACE1 inhibitor (Fig. 3C,D).

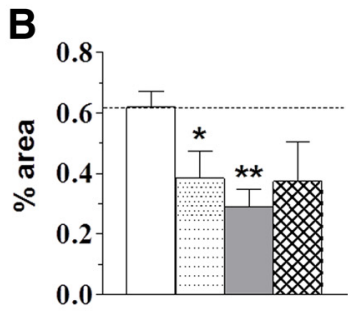

D

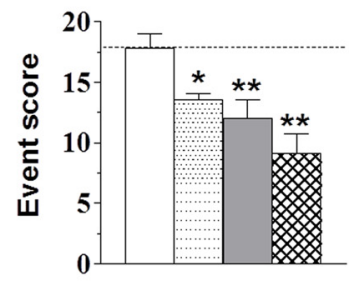

$\mathbf{F}$

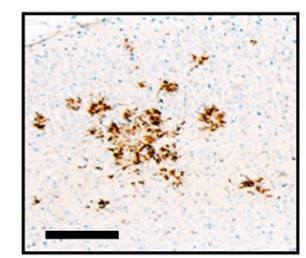

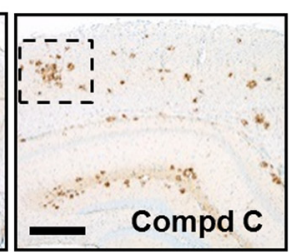

Figure 3. Chronic BACE1 inhibition led to reduction in dystrophic neurites and astrocytosis and to enhanced microglial activation in the brains of aged Tg2576 mice. $A$, Dystrophic neurites revealed using de0lmos silver stain in vehicle and $1.1 \mu \mathrm{g} / \mathrm{d}$ -treated mice. D. Compound ( dose-dependently reduced astrocytosis, scored as the number of clusters (events) per

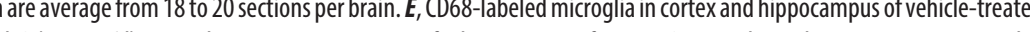
activation around plaques with compound C treatment. Microglial activation measured as percentage CD68-positive area relative to the area occupied by amyloid plaques (Thakker et al., 2009). ${ }^{*} p<0.05,{ }^{* *} p<0.01$, significantly different from vehicle-treated mice. Scale bars: $\boldsymbol{A}, \boldsymbol{C}, \boldsymbol{F}, 200 \mu \mathrm{m} ; \boldsymbol{E}, 500 \mu \mathrm{m}$.

Staining for CD68, a marker for phagocytic activity, revealed clusters of intensely stained microglia with relatively short processes surrounding the deposited amyloid (Fig. $3 E, F)$. Whereas subcutaneous delivery had no effects $(p=0.7)$, intracerebroventricular infusion of the compound augmented microglial activation $\sim 2$-fold in both cortex and hippocampus (Fig. 3G). A significant inverse correlation was apparent between activated microglia and amyloid burden in the cortex $\left(R^{2}=0.902, p<\right.$ $0.0001)$ and hippocampus $\left(R^{2}=0.704, p<0.0001\right)$, indicating a strong association between the two outcomes after chronic BACE1 inhibition.

Pilot work, assessing effects on brain $\mathrm{A} \beta$ after 2 week intracerebroventricular infusion in the Tg2576 mice, helped define compound doses $(0.3$ and $1.1 \mu \mathrm{g} / \mathrm{d})$ for chronic evaluation in this 
study. A feasibly high dose of $23.5 \mu \mathrm{g} / \mathrm{d}$ was incorporated to assess maximal efficacy in different endpoints and any dose-dependent toxicity with BACE1 inhibition in the study. We observed maximal reversal of the behavioral deficit and amyloid pathology in aged Tg2576 mice at $1.1 \mu \mathrm{g} / \mathrm{d}$ infusions, and no additional statistically significant benefit at $23.5 \mu \mathrm{g} / \mathrm{d}$ for any outcomes. Overall mortality (11.8\%) during blind execution of the study was within expected limits for aged mice. At study completion, the groups associated with mortality were uncovered as follows: Tg2576 mice infused intracerebroventricularly with vehicle (1 of 14), compound $\mathrm{C}$ at $1.11 \mu \mathrm{g} / \mathrm{d}$ ( 1 of 13); or $23.52 \mu \mathrm{g} / \mathrm{d}$ (6 of 12); WT mice infused intracerebroventricularly with vehicle (1 of 10) or subcutaneously with $1.11 \mu \mathrm{g} / \mathrm{d}$ compound C (4 of 10). Higher mortality was evident in transgenic mice receiving intracerebroventricular dose of $23.5 \mu \mathrm{g} / \mathrm{d}$ and in WT mice receiving subcutaneous dose at $1.11 \mu \mathrm{g} / \mathrm{d}$.

We evaluated the consequences of chronic compound C dosing on central and peripheral myelination and neuromuscular function, since BACE1 knock-down was associated with myelin abnormalities (Hu et al., 2006; Willem et al., 2006). Staining for myelin basic protein revealed no significant changes in myelin integrity in the corpus callosum or striatum. $G$-ratio measurements revealed no treatment effects on sciatic nerve myelination (Table 1). Neuromuscular function remained intact, as evidenced by lack of significant differences in grip strength between vehicle-treated and compound C-treated animals (Table 1).

\section{Discussion}

In this study, we demonstrate for the first time that chronic BACE1 inhibition in aged Tg2576 mice can reduce brain amyloid to levels below that at start of treatment and rescue deficits in contextual fear memory. A robust increase in microglial ramification, associated with brain amyloid reduction, suggests recruitment of novel clearance pathways following BACE1 inhibition in aged transgenic mice.

We sought proof-of-concept of whether chronic intracerebroventricular infusion of a potent BACE1 inhibitor can reduce brain amyloid and/or improve function in aged Tg2576 mice, despite high P-glycoprotein-mediated efflux from the brain (Meredith et al., 2008). Intracerebroventricular doses $\leq 1.1 \mu \mathrm{g} / \mathrm{d}$ produced robust brain exposures that were well tolerated and revealed maximal efficacy. In contrast, intracerebroventricular infusion at $23.5 \mu \mathrm{g} / \mathrm{d}$ or subcutaneous infusion at $1.1 \mu \mathrm{g} / \mathrm{d}$ led to high mortality. Deaths were likely due to high compound exposures leading to non-BACE1-mediated toxicity, given lack of any changes in myelin integrity or neuromuscular function unlike BACE1 knock-out mice (Hu et al., 2006; Willem et al., 2006). A recent trial with an orally bioavailable BACE1 inhibitor was terminated due to nonspecific retinal degeneration, with similar toxicity observed in BACE1 knock-out mice (May et al., 2011). In light of these data, we illustrate that low-dose intracerebroventricular BACE1 inhibitor can improve function with lower risk of adverse effects.

The BACE1 inhibitor elicited a significant improvement in contextual fear memory as well as attenuation of dystrophic neurites and astrocytosis in the brain of aged transgenics. Although pathogenesis is unclear, age-dependent increase in brain $\mathrm{A} \beta$ may drive soluble oligomeric species to alter synaptic transmission and calcium handling in neurons, ultimately leading to structural and behavioral deficits (Cleary et al., 2005; Venkitaramani et al., 2007; Shankar et al., 2008). We hypothesize that such deficits may be mitigated following robust reduction in brain A $\beta 42$ as well as amyloid plaques after intracerebroventricular BACE1 inhibition.
Further, BACE1 inhibition may ameliorate such deficits via modulation of cAMP-dependent CREB pathways, a critical component of long-term synaptic plasticity (Chen et al., 2012).

Previous studies have shown modest reductions in brain $\mathrm{A} \beta$ after 6 months of intraperitoneal injections with a BACE1 inhibitor (Fukumoto et al., 2010), while others have demonstrated lack of efficacy with secretase inhibition after significant amyloid has deposited in Tg2576 mice (Das et al., 2012). Particularly for BACE1 inhibitors, low efficacy may also be due to the enzyme's high affinity for $\mathrm{APP}_{\mathrm{SWE}}$ expressed in Tg2576 mice (Eketjäll et al., 2013). Together, our data of robust amyloid reduction below baseline suggest that, in addition to lowering $A \beta$ synthesis, the intracerebroventricularly delivered BACE1 inhibitor may reduce brain amyloid via yet-unknown mechanisms.

Intriguingly, the BACE1 inhibitor produced a dosedependent increase in microglial ramification that inversely correlated with amyloid burden. Microglia play a key role in amyloid clearance by phagocytosing brain $\mathrm{A} \beta$ (Koenigsknecht-Talboo et al., 2008) but also in neuroinflammation (Weitz and Town, 2012). Pulse-chase studies to evaluate the synthesis and clearance rates for CSF $A \beta$ have uncovered a significant impairment of $A \beta$ clearance in AD (Mawuenyega et al., 2010), advocating for CNS amyloid clearance as a plausible therapy for AD. Further, studies demonstrate that enhanced amyloid clearance, when combined with reduced $\mathrm{A} \beta$ synthesis, effectively attenuates brain amyloid burden (Wang et al., 2011). Accordingly, we hypothesize that an increase in microglia-mediated clearance together with reduced $\mathrm{A} \beta$ synthesis, ensuing from chronic BACE1 inhibition, results in robust brain amyloid reduction in aged Tg2576 mice. Our hypothesis is supported by several recent studies implicating microglial pathways, such as pathways involving TREM2 (the triggering receptor expressed on myeloid cells-2), CD33, the scavenger receptor Scara1, and autophagy in $\mathrm{A} \beta$ clearance and AD pathogenesis (Jiang et al., 2013; Griciuc et al., 2013; Frenkel et al., 2013; Lucin et al., 2013).

In summary, we demonstrate functional improvement, along with significant brain amyloid reduction and enhanced microglial ramification, with a potent BACE1 inhibitor in aged Tg2576 mice. Our results provide novel insights in aged transgenics, and support evaluation of potent BACE1 inhibitors in AD subjects.

\section{References}

Aisen PS, Vellas B, Hampel H (2013) Moving towards early clinical trials for amyloid-targeted therapy in Alzheimer's disease. Nat Rev Drug Discov 12:324-325. CrossRef Medline

Chen Y, Huang X, Zhang YW, Rockenstein E, Bu G, Golde TE, Masliah E, Xu $\mathrm{H}$ (2012) Alzheimer's $\beta$-secretase (BACE1) regulates the cAMP/PKA/ CREB pathway independently of $\beta$-amyloid. J Neurosci 32:11390-11395. CrossRef Medline

Cleary JP, Walsh DM, Hofmeister JJ, Shankar GM, Kuskowski MA, Selkoe DJ, Ashe KH (2005) Natural oligomers of the amyloid- $\beta$ protein specifically disrupt cognitive function. Nat Neurosci 8:79-84. CrossRef Medline

Das P, Verbeeck C, Minter L, Chakrabarty P, Felsenstein K, Kukar T, Maharvi G, Fauq A, Osborne BA, Golde TE (2012) Transient pharmacologiclowering of $A \beta$ production prior to deposition results in sustained reduction of amyloid plaque pathology. Mol Neurodegener 7:39. CrossRef Medline

Easton A, Sankaranarayanan S, Tanghe A, Terwel D, Lin AX, Hoque N, Bourin C, Gu H, Ahlijanian M, Bristow L (2013) Effects of sub-chronic donepezil on brain Abeta and cognition in a mouse model of Alzheimer's disease. Psychopharmacology 230:279-289. CrossRef Medline

Eketjäll S, Janson J, Jeppsson F, Svanhagen A, Kolmodin K, Gustavsson S, Radesäter AC, Eliason K, Briem S, Appelkvist P, Niva C, Berg AL, Karlström S, Swahn BM, Fälting J (2013) AZ-4217: a high potency BACE inhibitor displaying acute central efficacy in different in vivo models and reduced amyloid deposition in Tg2576 mice. J Neurosci 33:10075-10084. CrossRef Medline 
Frenkel D, Wilkinson K, Zhao L, Hickman SE, Means TK, Puckett L, Farfara D, Kingery ND, Weiner HL, El Khoury J (2013) Scaral deficiency impairs clearance of soluble amyloid- $\beta$ by mononuclear phagocytes and accelerates Alzheimer's-like disease progression. Nat Commun 4:2030. CrossRef Medline

Fukumoto H, Takahashi H, Tarui N, Matsui J, Tomita T, Hirode M, Sagayama M, Maeda R, Kawamoto M, Hirai K, Terauchi J, Sakura Y, Kakihana M, Kato K, Iwatsubo T, Miyamoto M (2010) A noncompetitive BACE1 inhibitor TAK-070 ameliorates $\mathrm{A} \beta$ pathology and behavioral deficits in a mouse model of Alzheimer's disease. J Neurosci 30:11157-11166. CrossRef Medline

Ghosh AK, Brindisi M, Tang J (2012) Developing $\beta$-secretase inhibitors for treatment of Alzheimer's disease. J Neurochem 120:71-83. CrossRef Medline

Griciuc A, Serrano-Pozo A, Parrado AR, Lesinski AN, Asselin CN, Mullin K, Hooli B, Choi SH, Hyman BT, Tanzi RE (2013) Alzheimer's disease risk gene CD33 inhibits microglial uptake of amyloid $\beta$. Neuron 78:631-643. CrossRef Medline

Hu X, Hicks CW, He W, Wong P, Macklin WB, Trapp BD, Yan R (2006) Bacel modulates myelination in the central and peripheral nervous system. Nat Neurosci 9:1520-1525. CrossRef Medline

Jacobsen JS, Wu CC, Redwine JM, Comery TA, Arias R, Bowlby M, Martone R, Morrison JH, Pangalos MN, Reinhart PH, Bloom FE (2006) Earlyonset behavioral and synaptic deficits in a mouse model of Alzheimer's disease. Proc Natl Acad Sci U S A 103:5161-5166. CrossRef Medline

Jiang T, Yu JT, Zhu XC, Tan L (2013) TREM2 in Alzheimer's disease. Mol Neurobiol 48:180-185. CrossRef Medline

Jonsson T, Atwal JK, Steinberg S, Snaedal J, Jonsson PV, Bjornsson S, Stefansson H, Sulem P, Gudbjartsson D, Maloney J, Hoyte K, Gustafson A, Liu Y, Lu Y, Bhangale T, Graham RR, Huttenlocher J, Bjornsdottir G, Andreassen OA, Jönsson EG, et al. (2012) A mutation in APP protects against Alzheimer's disease and age-related cognitive decline. Nature 488:96-99. CrossRef Medline

Kawarabayashi T, Younkin LH, Saido TC, Shoji M, Ashe KH, Younkin SG (2001) Age-dependent changes in brain, CSF, and plasma amyloid- $\beta$ protein in the Tg2576 transgenic mouse model of Alzheimer's disease. J Neurosci 21:372-381. Medline

Koenigsknecht-Talboo J, Meyer-Luehmann M, Parsadanian M, GarciaAlloza M, Finn MB, Hyman BT, Bacskai BJ, Holtzman DM (2008) Rapid microglial response around amyloid pathology after systemic anti-A $\beta$ antibody administration in PDAPP mice. J Neurosci 28:1415614164. CrossRef Medline

Lucin KM, O’Brien CE, Bieri G, Czirr E, Mosher KI, Abbey RJ, Mastroeni DF, Rogers J, Spencer B, Masliah E, Wyss-Coray T (2013) Microglial beclin 1 regulates retromer trafficking and phagocytosis and is impaired in Alzheimer's disease. Neuron 79:873-886. CrossRef Medline

Mawuenyega KG, Sigurdson W, Ovod V, Munsell L, Kasten T, Morris JC, Yarasheski KE, Bateman RJ (2010) Decreased clearance of CNS $\beta$-amyloid in Alzheimer's disease. Science 330:1774. CrossRef Medline

May PC, Dean RA, Lowe SL, Martenyi F, Sheehan SM, Boggs LN, Monk SA, Mathes BM, Mergott DJ, Watson BM, Stout SL, Timm DE, Smith Labell E, Gonzales CR, Nakano M, Jhee SS, Yen M, Ereshefsky L, Lindstrom TD,
Calligaro DO, et al. (2011) Robust central reduction of amyloid- $\beta$ in humans with an orally available, non-peptidic $\beta$-BACE1 inhibitor. J Neurosci 31:16507-16516. CrossRef Medline

Meredith JE Jr, Thompson LA, Toyn JH, Marcin L, Barten DM, Marcinkeviciene J, Kopcho L, Kim Y, Lin A, Guss V, Burton C, Iben L, Polson C, Cantone J, Ford M, Drexler D, Fiedler T, Lentz KA, Grace JE Jr, Kolb J, et al. (2008) P-glycoprotein efflux and other factors limit brain amyloid beta reduction by beta-site amyloid precursor protein-cleaving enzyme 1 inhibitors in mice. J Pharmacol Exp Ther 326:502-513. CrossRef Medline

Sankaranarayanan S, Price EA, Wu G, Crouthamel MC, Shi XP, Tugusheva K, Tyler KX, Kahana J, Ellis J, Jin L, Steele T, Stachel S, Coburn C, Simon AJ (2008) In vivo beta-BACE1-1 inhibition leads to brain Abeta lowering and increased alpha-BACE1 processing of amyloid precursor protein without effect on neuregulin-1. J Pharmacol Exp Ther 324:957-969. Medline

Shankar GM, Li S, Mehta TH, Garcia-Munoz A, Shepardson NE, Smith I, Brett FM, Farrell MA, Rowan MJ, Lemere CA, Regan CM, Walsh DM, Sabatini BL, Selkoe DJ (2008) Amyloid- $\beta$ protein dimers isolated directly from Alzheimer's brains impair synaptic plasticity and memory. Nat Med 14:837-842. CrossRef Medline

Thakker DR, Weatherspoon MR, Harrison J, Keene TE, Lane DS, Kaemmerer WF, Stewart GR, Shafer LL (2009) Intracerebroventricular amyloid- $\beta$ antibodies reduce cerebral amyloid angiopathy and associated microhemorrhages in aged Tg2576 mice. Proc Natl Acad Sci U S A 106:45014506. CrossRef Medline

Toyn JH, Ahlijanian MK (2014) Interpreting Alzheimer's disease clinical trials in light of the effects on amyloid- $\beta$. Alzheimers Res Ther 6:14. CrossRef Medline

Vassar R, Kovacs DM, Yan R, Wong PC (2009) The $\beta$-secretase enzyme BACE in health and Alzheimer's disease: regulation, cell biology, function, and therapeutic potential. J Neurosci 29:12787-12794. CrossRef Medline

Venkitaramani DV, Chin J, Netzer WJ, Gouras GK, Lesne S, Malinow R, Lombroso PJ (2007) $\beta$-Amyloid modulation of synaptic transmission and plasticity. J Neurosci 27:11832-11837. CrossRef Medline

Wang A, Das P, Switzer RC 3rd, Golde TE, Jankowsky JL (2011) Robust amyloid clearance in a mouse model of Alzheimer's disease provides novel insights into the mechanism of amyloid-immunotherapy. J Neurosci 31:4124-4136. CrossRef Medline

Weitz TM, Town T (2012) Microglia in Alzheimer's disease: it's all about context. Int J Alzheimers Dis 2012:314185. CrossRef Medline

Willem M, Garratt AN, Novak B, Citron M, Kaufmann S, Rittger A, DeStrooper B, Saftig P, Birchmeier C, Haass C (2006) Control of peripheral nerve myelination by the $\beta$-secretase BACE1. Science 314:664666. CrossRef Medline

Yan R, Vassar R (2014) Targeting the $\beta$ secretase BACE1 for Alzheimer's disease therapy. Lancet Neurol 13:319-329. CrossRef Medline

Zhao J, Fu Y, Yasvoina M, Shao P, Hitt B, O'Connor T, Logan S, Maus E, Citron M, Berry R, Binder L, Vassar R (2007) $\beta$-Site amyloid precursor protein cleaving enzymel levels become elevated in neurons around amyloid plaques: implications for Alzheimer's disease pathogenesis. J Neurosci 27:3639-3649. Medline 